\title{
Turismo y medio ambiente: El caso de Acapulco
}

\author{
Juan Manuel Ramírez Sáiz
}

El propósito de este artículo es analizar el proceso de desarrollo de Acapulco, la actividad turistica y el medio ambiente. Para ello se dividió el análisis en tres periodos, cada uno de ellos asociado a un factor determinante de la estructura del espacio turístico: el suelo urbano, la estructura urbana y la contaminación. Se concluye que la imprevisión urbana $y$ ambiental, así, como el desarrollo acelerado del turismo han afectado a la economia, al medio ambiente y a la calidad de vida. En las conclusiones se propone que se apliquen una serie de medidas correctivas; se destaca la importancia de seguir una planeación preventiva, tanto urbana como ambiental, y el manejo adecuado de los recursos naturales de los centros turísticos.

\section{Introducción}

La ciudad de Acapulco constituye todavía uno de los centros turísticos importantes del mundo. Sin lugar a dudas, es el complejo vacacional más grande de los países en desarrollo, asi como líder del turismo latinoamericano y evidentemente del mexicano. Sus 560 establecimientos para hospedaje, 24000 cuartos para turistas, 386 restaurantes y bares, 23 clubs nocturnos y discotecas, 385 embarcaciones para pesca deportiva y esqui náutico, 550 automóviles para renta y 65 agencias de viaje son prueba de ello ${ }^{1}$ (véase plano). La actividad turística es, a todas luces, el eje de la economía local, y ha desplazado a las restantes. El municipio de Acapulco no posee una producción agropecuaria ni industrial significativa, y la cabecera del mismo es una ciudad terciarizada que, sin embargo, no cuenta con sitios de interés cultural o histórico (cuadro 1).

El punto de partida de su espectacular desarrollo como centro turístico mundial reside en tres factores de distinta índole: natural, locacional y financiera. Éstos son: los atractivos naturales de sus costas y playas, el estar ubicado en el corazón del área turística nortea-

1 Según SEctur, el número de cuartos en 1984 era 16 431; esta cifra no incluye hoteles de clase económica ni alojamiento diferente al hotelero. Véase Secretaría de Turismo: "Estadísticas Básicas de la Actividad Turistica", México, 1985, p. 40.

El número de establecimientos, de agencias de viaje y de cuartos fue obtenido de: Instituto Mexicano de Investigaciones Turísticas: "Indicadores Económicos" s.f. p. 4, mimeo.

La información restante fue tomada de Geazcs: "Les amenagements touristiques au Mexique", Centre de Hautes Etudes Tourtstiques, Aix, en Provence, France, 1980, Etudes et memoires, 38, p. 208. 


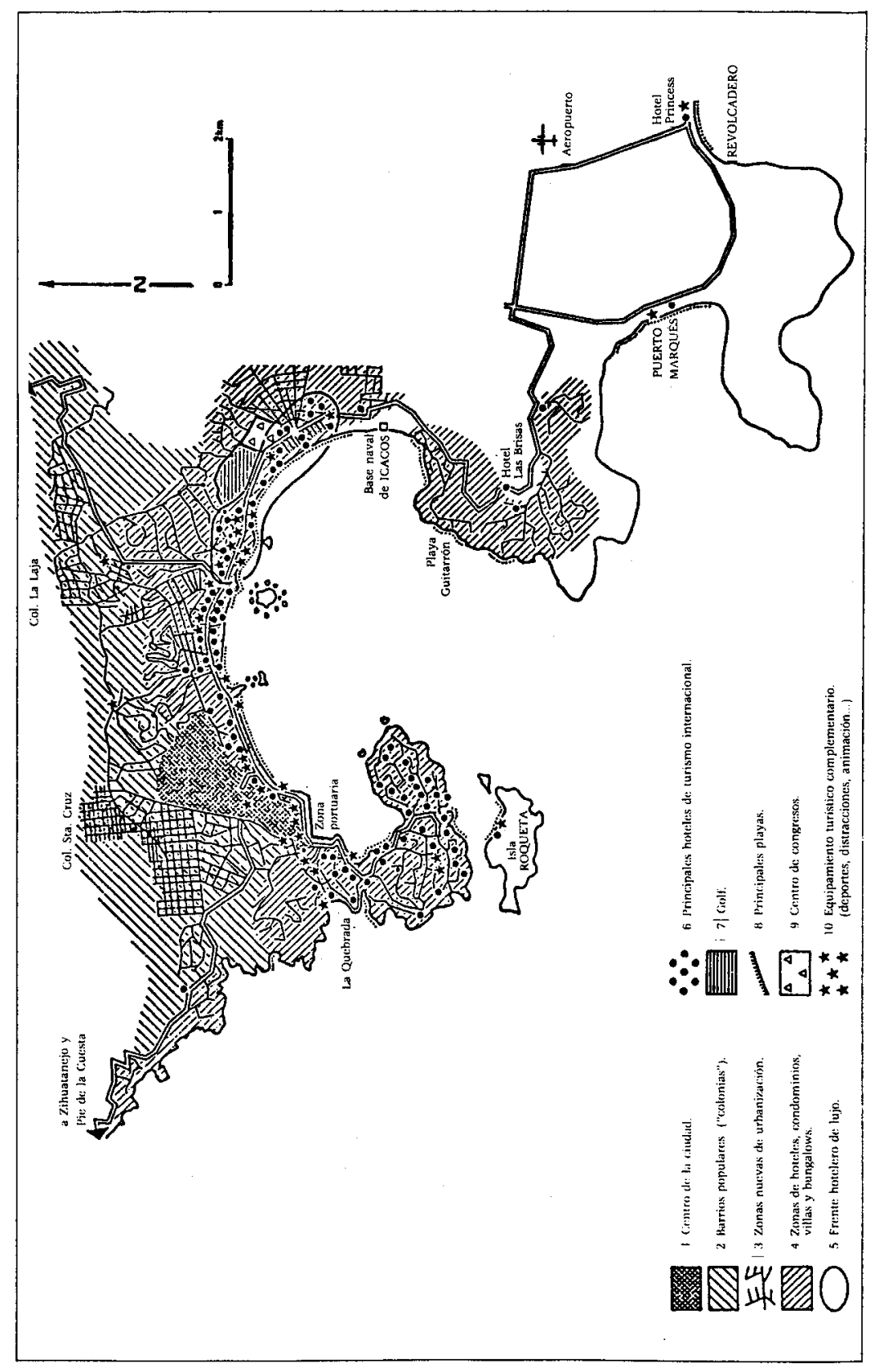




\section{CUADRO 1}

Municipio de Acapulco: PEA por rama de actividad (porcentajes)

\begin{tabular}{llllllllll}
\hline \multicolumn{1}{c}{ A ñoAgricult. Extrac. Transt. Construc. } & Elect. $y$ Gas & Comere. Servicios Petróleo Gobierno \\
\hline 1940 & 65.7 & - & 8.1 & 2.5 & 0.3 & 9.3 & - & - & - \\
1950 & 43.05 & 0.45 & 9.34 & 6.22 & 0.39 & 10.94 & 19.42 & - & - \\
1960 & 39.3 & 0.3 & 12.0 & 6.5 & 0.6 & 12.7 & 26.5 & - & - \\
1970 & 19.1 & 0.2 & 10.1 & 7.6 & 0.46 & 12.7 & 33.08 & 0.1 & 3.8 \\
1980 & 12.6 & 0.1 & 6.0 & 6.4 & 0.13 & 16.8 & $\mathbf{4}^{4}$ & - & - \\
\hline
\end{tabular}

Fuente: V, VI, VII, VIII, IX y X Censos de Poblacion y Vivenda.

mericana y las fuertes inversiones (tanto privadas y públicas como nacionales y extranjeras) realizadas para la in fraestructura hotelera del puerto.

La riqueza natural de Acapulco la constituye una magnífica bahía en anfiteatro, larga y profunda, pero protegida del mar abierto por una península y varias islas y bordeada por una playa arenosa de 13 kilómetros de longitud, a la cual el desarrollo turístico ha anexado otra pequeña que va hasta Revolcadero, en el sureste, antes del aeropuerto. ${ }^{2}$ Estos recursos naturales y ambientales han sido la base del desarrollo turístico de Acapulco, y su espléndido escenario es realzado y explotado por la compleja infraestructura hotelera de que dispone la ciudad. ${ }^{3}$ Por ello, el espacio turístico de Acapulco viene dado tanto por el medio ambiente como por los elementos de la estructura urbana. El análisis de ambos factores durante los cincuenta y ocho últimos años de su historia es necesario para comprender el origen, evolución y perspectivas de este centro recreativo y de diversión. Dicho análisis se ha dividido en tres periodos, los cuales acotan las etapas más significativas del desarrollo de Acapulco; a la consideración de dichas etapas se asocia el estudio de factores determinantes de la estructura del espacio turístico. Los periodos son: a) 1927-1954: el despegue de la actividad turística; b) 1955-1971: el auge turístico, y c) 1972-1985: el estancamiento y la aplicación de medidas correctivas. Aunque los factores asociados no son exclusivos del periodo en que se consideran, su inclusión responde a la importancia que, en cada caso, adquieren y que amerita, respectivamente, un análisis particular; por ello, su estudio se efectúa articulando el tópico al periodo en cuestión pero, al mismo

2 Cazes, G., op. cit. p. 206.

3 Gormsen, E. y otros, El turismo como factor de desarrollo regional en México, Mainz, Alemania, 1977, pp. 86 y 92. 
tiempo, con templándolo bajo la óptica de la totalidad del lapso estudiado: 1927-1985. Estos factores son: a) el suelo urbano, en el primer periodo; b) la estructura urbana, en el segundo, y c) la contaminación, en el tercero.

Este enfoque parte de dos premisas. La primera gira en torno a la estrecha vinculación que existe, en un centro vacacional, entre el suelo, la estructura urbana y la actividad turistica. La segunda premisa parte del supuesto de que la relación entre turismo y medio ambente es significativa no sólo descle el momento en que el primero afecta negativamente al segundo, sino a partir del instante en que la actividad turistica descubre el potencial que un ambiente dado ofrece a su desarrollo. La forma en que se conciba esta relación y, en particular, el uso que se establezca del recurso natural son los que determinarán su dinámica ambiental. Por supuesto, ambas premisas no son independientes. Por ello, el tipo de incorporación que se haga de la tierra agrícola al proyecto turístico, la manera en que se condicione la evolución de la estructura urbana del centro vacacional, la medida en que se responda a las necesidades de alojamiento y servicios no sólo de los turistas sino de la población residente serán los factores causales de la calidad del ambiente turístico.

\section{El despegue de la actividad turistica: 1927-1954}

Este periodo se abre con la re-articulación del puerto de Acapulco al pais y su "descubrimiento" por parte de los mexicanos, especialmente de los residentes en el Distrito Federal, y en él se manifiesta el peso que para su futuro desarrollo tuvo la incorporación de tierra agricola sobre todo de origen ejidal.

\subsection{El resurgimiento de un puerto olvidado}

Después de la independencia de México respecto de España (1821), se suspendió el tráfico maritimo que Acapulco mantenía con Manila. Esta actividad comercial constituía el eje de la vida económica del puerto. Por ello, su cancelación trajo consigo el estancamiento de la ciudad, que subsistió como una pequeña villa aislada y sin importancia. En noviembre de 1927, se rompe este aislamiento al construirse la carretera Acapulco-Taxco que, a través del tramo Cuernavaca-D.F. unió al puerto con la capital de la república. ${ }^{+}$ Ella permitió tanto a nacionales como norteamericanos "descubrir"

\footnotetext{
+ Cimmejana, la, "Acapuleo: despojo y turismo", en moblonas del desconollo.

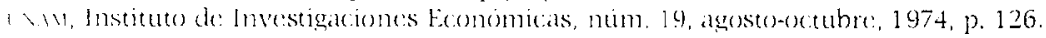


la belleza de las playas de Acapulco y dinamizar, de nuevo, la vida de la ciudad, de tal manera que en 1928 disponía ya de aeropuerto. ${ }^{5}$ Sin embargo, la estructura urbana y los servicios correspondientes eran primarios; la actividad turistica era limitada y la fisonomia de la bahía apenas cambió.

Las primeras construcciones se edifican en 1934 sobre la península de las Playas que fue la zona pionera en urbanizarse para el turismo. En la década de los treinta se constituyen también los primeros grandes hoteles y en 1944 surgen otros nuevos. ${ }^{6}$ Este ritmo creciente de edificación hotelera está relacionado con dos hechos. El primero fue la coyuntura de la Segunda Guerra Mundial, la cual implicó la clausura tem poral de los destinos turísticos europeos para los turistas norteamericanos, quienes encontraron una alternativa en el naciente centro mexicano. El fin de este conflicto armado benefició igualmente a Acapulco, ya que el gobierno norteamericano seleccionó a La Habana y Acapulco, entre otros, como lugares para la recuperación de los ex combatientes estadounidenses de la guerra mundial y posteriormente de los que participaron en la de Corea. ${ }^{7}$ El segundo factor que impulsó la construcción de hoteles fue la campaña lanzada por el presidente Ávila Camacho y que tituló "peso contra peso"; a través de ella, el Estado mexicano se comprometía a aportar igual cantidad que la que invirtiera el capital privado para la promoción turística. ${ }^{8}$ Esta aportación se materializó en el financiamiento de infraestructura y servicios para el nuevo centro vacacional.

La afluencia turística, tanto nacional como extranjera, hacia Acapulco se incrementa en este periodo. Después de la Segunda Guerra Mundial comienzan además a generarse olas migratorias, desde el propio municipio y los circunvecinos del Estado, hacia el principal centro urbano de Guerrero. Pero el crecimiento de la población se aceleró sobre todo a partir de 1960, como puede apreciarse en el cuadro 2 .

La fisonomía de la ciudad va modificándose. El viejo casco urbano concentraba en los años treinta, en torno al área del zócalo, las funciones políticas, administrativas y comerciales así como las zonas residenciales y barrios populares. Pero a partir de los años cuarenta, esta estructura básica se va transformando. Surgen los prime-

S Cazes, G., op. cit., p. 208.

${ }^{6}$ De la Peña, M.T., Guerrero Economico, Mexico. Talleres Gráficos de Adrian Sánchez, 1949, tomo II, p. 564.

"Gómezjara, F., "Acapulco: el paraiso perdido" en Hahitacion, Forlsssir, Mixico, 11úms. 7-8, julio-diciembre, 1982, p. 104

${ }^{8}$ Cazes, G., op cit., p. 74 
$(.11,1) 1202$

Población del municipio y ciudad de Acapulco

\begin{tabular}{lcc}
\hline & Poblacion & \\
\hline año & municipio & ciudad \\
& & \\
1950 & 55862 & 29512 \\
1960 & 84720 & 49149 \\
1970 & 238714 & 174378 \\
1980 & 409335 & 301902 \\
\hline
\end{tabular}

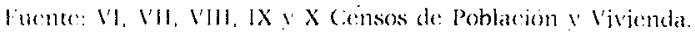

ros fraccionamientos y las zonas residenciales. ${ }^{9}$ Se trazan calles para la urbanización de la bahía; se afectan varias playas para la construcción de la arteria vial más importante de la ciudad (La Costera); se traslada el viejo aeropuerto fuera de la bahía y se inicia la construcción de la autopista Acapulco-Distrito Federal. ${ }^{11}$ A través de estas medidas, se estaban creando las bases para la expansión de este centro urbano. El autor principal de estos cambios fue el presidente Miguel Alemán V. (1946-1952) quien, además, fue fundador de la cadena hotelera "Continental"." Para coordinar estos proyectos, se creó en 1945 la Junta Federal de Mejoras Materiales; dicha Junta reinició asimismo las obras de saneamiento y alumbrado que comenzaron bajo la presidencia de Emilio Portes Gil. Sin embargo, la dinámica poblacional rebasó estos incipientes intentos de planificación de la ciudad y en 1946 aparecen, por invasión, las primeras colonias populares.

\subsection{La tierra, soporte de la infraestructura turistica}

Durante los dieciocho años que comprende el periodo, Acapulco se convierte en el balneario de playa más cercano a la capital de la república y en un centro turístico ante el que muestran interés creciente los vacacionistas norteamericanos. Las transformaciones que va sufriendo la vieja ciudad y la construcción progresiva de residencias y hoteles no hubieran sido posibles sin la política que se adoptó

9 Conde G., N. R., "Algunas consideraciones sobre el desarrollo capitalista, la lucha de clases, la producción de estructura urbana y los procesos de urbanización en la región acapulqucña", tesis profesional, Facultad de Ciencias Políticas y Sociales, UNMM, 1982, p. 29.

\footnotetext{
11) Gormsen, E., op. cit., p. 37.

11 Cazes, G., op cit., p. t8.
} 
frente al insumo básico de todo desarrollo urbano y turístico, es decir, la tierra, especialmente la cercana a las playas. Excluyendo su zona federal (la cual, según la Constitución política, es propiedad de la nación), en Acapulco, como en la mayoría de las ciudades mexicanas, la tierra próxima a la ciudad era en gran parte - es decir, no exclusivamente- ejidal. ${ }^{12} \mathrm{Su}$ uso agrícola fue perdiendo importancia, frente a las ganancias que se podian derivar de su utilización como suelo urbano o urbanizable. Y su expropiación se justificó para facilitar la actividad turística de la cual, supuestamente, se derivarían beneficios para la ciudad y el conjunto de la población. Bajo esta premisa, ya en 1928 (un año después de inaugurarse la primera carretera Acapulco-D.F.) el Ayuntamiento pone a la venta a muy bajos precios, y regala a los vecinos más distinguidos, los terrenos del antiguo ejido colonial. ${ }^{\text {i. }}$

A través de este procedimiento, adquirieron propiedades inmuebles comerciantes que posteriormente ampliaron sus actividades como fraccionadores y hoteleros. Esta política municipal sobre la tierra fue secundada por el gobierno del estado de Guerrero. En 1932 el gobernador, general Castrejón, expropió los terrenos del litoral de la bahía llamados Las Huertas, desde el castillo de San Diego - al lado del hotel Las Hamacas - hasta playa Hornos, donde en la actualidad se encuentra el parque Papagayo. ${ }^{14}$ Como afirma M. A. Gómez, esta operación fue posible por presiones de origen federal, afectando tanto la propiedad privada y comunal como la jurisdicción municipal y estatal. 15

Un ejemplo de la historia y destino de la tierra ejidal en Acapulco es el del ejido Icacos. El 9 de noviembre de 1940, de las 726 hectáreas que el presidente Lázaro Cárdenas había aprobado como dotación ejidal a favor de los campesinos de la zona, él mismo autorizó

\footnotetext{
12 El ejido es la tierra que se entrega a los campesinos, dentro del marco de la reforma agraria, ya sea destinada a uso colectivo o individual de los integrantes de una comunidad. El ejido es una totalidad, no la suma de sus parcelas. Está regido por reglas que lo hacen similar a una organización cooperativa. Confiere derechos inalienables y los miembros del ejido no pueden vender las tierras; el derecho del ejidatario sólo se trasmite por herencia. Véase Gutelman, M., Capitalismo y reforma agraria en México, edic. Era, México, 1974, p. 125.

13 Gómezjara, F., "Acapulco: despajo y turismo", op. cit., p. 128. En otro escrito, el autor lo califica como antiguo ejido virreynal. La denominación de antiguo ejido no precisa si, en el momento de la "donación", el predio en cuestión era tierra ejidal. En todo caso, no encontré referencias sobre las condiciones en que se realizó la "expropiación".

14 Gómezjara, F., "Acapulco: el paraiso perdido", op. cit., p. 104.

15 Gómez Maganda: Acapulco en mi vida y en mi tiempo, México, Costa Amic; 1955, pp. 42 y 43.
} 
la expropiación de 76 hectáreas y, al correr los años, se instalan ahí los hoteles Holiday Inn, los condominios Playa Sol y las Torres Gemelas. Cuatro años más tarde, (17 enero de 1945), se le expropia, por decreto presidencial, 1 hectárea y 7 áreas a favor de Petróleos Mexicanos (PEMEX); en la superficie expropiada, la Secretaria de Marina instalaría posteriormente la base naval de Icacos. En los terrenos restantes del ex ejido se formó después la zona residencial Costa Azul. El final de este ejido fue la destrucción, en 1960, del cementerio, cuyos terrenos pasaron a propiedad de la Junta Federal de Mejoras Materiales quien, a su vez, los puso a disposición del "crecimiento turístico del puerto".

Las intervenciones sobre la tierra del puerto y los ejidos no se reducen a las reseñadas. El 11 de agosto de 1942, el secretario de Obras Públicas entrega la concesión de las playas de Caleta y Caletilla, propiedad federal, a su esposa la señora Riccordi. ${ }^{16}$ Durante su periodo presidencial, M. Alemán V. autorizó la expropiación de 14 ejidos para impulsar el desarrollo del turismo en el puerto; en 1947 en particular, Miguel Alemán aprobó la expropiación del ejido Puerto Marqués, convirtiéndolo en 124 granjas de 6 hectáreas cada una. Entre los compradores figuran funcionarios públicos o familiares directos de ellos. ${ }^{17}$ Sobre este ex ejido se construiría más tarde el lujoso hotel Pierre Marques. Asimismo el famoso fraccionamiento Las Brisas se alza sobre tierra que, en 1950, fue arrebatada a campesinos por la fraccionadora Aburto S.A., cuyo propietario, Enrique Aburto Palacios, llegaría después a la gubernatura del estado de Guerrero. ${ }^{18}$ Finalmente en 1981, a solicitud del gobernador Rubén Figueroa, se expropian 327 hectáreas de los terrenos de la Sabana para crear el centro de población El Renacimiento. ${ }^{19}$

16 Gomezjara, F.: "Acapulco: el paraiso perdido", op. cit. p. 106

17 Entre los compradores del ex ejido se encontraban: Carlos I. Serrano, Antonio Diaz Lombardo, Gómez Maganda, Sánchez Celis, Soledad Ávila Camacho, Antonio Camacho, Antonio Carrillo Flores, Alberto Braniff, Elias Suraski y Antonio Domit.

18 Ricardo Garibay ofrece la siguiente "lista de los que eran grandes terratenientes de Acapulco, llamados también fraccionadores o invasores de ejidos: 'Alberto Pullan (peninsula de: Las Playas), Wolfgang Schoenborn (Costa Azul, hasta frente a Icacos), Juan Andreu Almazán (del fuerte Diana hasta La Laja y hasta La Picuda), Gilberto R. Limón (Icacos), Enrique Aburto Palacios (Las Brisas), ...don Emilio Azcárraga, el coronel Serrano (desde la base naval hasta Puerto Marqués, inclusive). La franja de los propietarios de la costera va de las playas hasta medio kilómetro tierra adentro, o sea toda la planicie frente al mar... Nadie da razón, o nadie quiere darla, de la parte que en esa cmpresa de ganancias al millón por uno ha tenido el Licenciado..."' (Miguel Alemán). Garibay, R., Acapulco, edit. Grijalbo, 1979. pp. 33 y 34.

19 López Portillo, J., "Sexto Informe de Gobierno, Sector Asentamientos Humanos", 1982, p. 146. 
Esta serie de expropiaciones demuestra que (contraviniendo su función social) el destino de los ejidos fue básicamente favorecer la concentración privada de la tierra y la especulación con ella, convirtiéndose fundamentalmente en soporte de desarrollos turísticos. En este proceso, el gobierno, a sus diferentes niveles (municipal, estatal y federal), no asumió el papel de regulador y ordenador de la incorporación de la tierra a usos urbanos en función del futuro de la actividad turística del puerto. Por el contrario, sus representantes actuaron como juez y parte cuando no buscaban su directo beneficio o el de personas y familiares estrechamente vinculados a ellos; es decir, en estas intervenciones de la autoridad, fue manifiesto el uso de la función pública para el provecho personal. Por otra parte, la secuencia de expulsiones de campesinos de tierras de las que eran legítimos propietarios, de expropiaciones ejidales a favor de comerciantes, hoteleros, inmobiliarias y funcionarios públi$\cos$, y de invasiones de tierra pública o privada, por parte de colonos, para resolver una necesidad perentoria de vivienda determinaron, en buena medida, la futura evolución de la ciudad y evidencian el punto problemático de partida sobre el que se fundamentó. La tierra fue objeto de despojo y enriquecimiento o soporte de una precaria vivienda. La ausencia de un plan de usos del suelo que regulara su incorporación al desarrollo urbano y turístico del puerto no era más que el reflejo de una concepción de la tierra como una fuente de ganancia para unos pocos o un simple medio, para muchos, de resolver una necesidad de techo. La visión del suelo urbano como un recurso limitado y cuyo mejor destino fuera definido de acuerdo con la estricta y generosa previsión de los diferentes requerimientos de un centro turístico de talla internacional (infraestructura, servicios y equipamiento urbanos asi como de áreas verdes, etc.) y dando prioridad a los intereses generales y de mediano o largo plazo por encima de los inmediatos y personales, no estuvo presente. A esta falta de perspectivas en el manejo de la tierra se debe que actualmente en Acapulco se registre una baja e irregular ocupación del suelo (baja densidad) combinada con una oferta casi nula del mismo. Ello provoca una alta especulación tanto para la compra como para la renta de terrenos urbanos.

El efecto final de estos procesos de utilización del suelo ha sido la falta de tierra urbanizable en el perímetro de la ciudad, la fuerte presión sobre tierra ya utilizada (en colonias populares principalmente) a fin de cambiar su uso y explotar el valor comercial que ha adquirido y el intento de lanzar proyectos urbanos y nuevos desarrollos turísticos ambiciosos, de alto costo y en zonas cada vez más alejadas del puerto. Sin embargo, los planes promovidos por la Se- 
cretaría de Desarrollo Urbano y Ecología (SEDUE) y Fideicomiso Acapulco (FIDACA) recientemente para crear reservas territoriales en la localidad están siendo frenados por la Secretaría de la Reforma Agraria, a] privilegiar ésta la regularización de la tenencia de la tierra, ${ }^{19 a}$ por las ventajas económicas y políticas que a ella reporta. Como es sabido, a esta Secretaría compete la tramitación de los expedientes expropiatorios.

2. El auge turístico y la expansión anárquica de la ciudad: 1955-1971

Los 16 años siguientes de la historia de Acapulco se caracterizan por un crecimiento acelerado e impresionante de la actividad turística, así como por la extensión de la mancha urbana.

\subsection{Acapulco, un centro turístico internacional}

A partir de 1955, el puerto de Acapulco se convierte en el lugar de moda para el turismo del jet set nacional y norteamericano. Los epítetos elogiosos se multiplican: "Riviera mexicana", "perla del Pacífico", "Paraíso a las puertas de EE.UU.", etc. Los factores que fueron creando este clima fueron varics. Para la afluencia turística mexicana, un hecho que facilitó el acercamiento al puerto fue la construcción de la vía rápida (carretera 95) o supercarretera D.F.-Cuernavaca en 1955. Obviamente esta facilidad de acceso se incrementó al ponerse en servicio el nuevo aeropuerto internacional en 1964 que permitía la operación de aviones tipo Jet. La mayor capacidad de los nuevos aviones y las facilidades otorgadas por las líneas aéreas internacionales (vuelos directos y precios módicos para viajeros en grupo) impulsaron el turismo masivo, a diferencia dt? que visitaba el puerto entre 1955 y 1964 que era más selectivo. Una rircunstancia que favoreció el surgimiento de Acapulco como centro tuístico mundial fue la clausura de uno de los puntos de atracción del turismo internacional (sobre todo para el vacacionista norteamericano), es decir, de La Habana, después del triunfo de la revolución en Cuba (1959) y la ruptura de relaciones con Estados Unidos. Pero el gran impulso provino de las fuertes inversiones tanto públicas y privadas como nacionales y extranjeras. En el periodo en cuestión, es aceptado que la participación de la iniciativa privada mexicana fue modesta en relación al rol de promotor que desempeñó el gobierno

\footnotetext{
$19 a$ SEDUE, Dirección General de Suelo Urbano: "Balance de resultados en materia de Suelo Urbano", II Congreso Hispanoamericano de Urbanismo, Tlaxcala, 1986.
} 
mexicano. Éste captó y orientó capitales, tomó a su cargo los costos considerables del equipamiento inicial, e intervino incluso en calidad de gestor directo de algunos medios de comunicación (Aeroméxico) y parte de la infraestructura hotelera (Nacional Hotelera). ${ }^{20}$ Lo anterior significa que "al Estado le ha correspondido cargar con el peso principal del equipamiento del país para el desarrollo del turismo. A través de medidas financieras, de estímulos fiscales y administrativos, de una capacidad constructora (sic) que no deja dudas y hasta de laxitud en la vigilancia de tarifas, precios y calidades del servicio, el Estado ha actuado como socio de los empresarios turísticos, quienes trabajan cuando la cosecha está madura". ${ }^{21}$ En cuanto a los hoteles de firmas extranjeras, predominó la intervención de grandes cadenas, las cuales posteriormente se fusionaron con las líneas aéreas y finalmente integraron complejos (transporte, alojamiento, etc.) o conglomerados financieros que controlan también actividades auxiliares como renta de vehículos, agencias y clubes de viajes, etc. ${ }^{22}$ En la mayoría de los hoteles, el porcentaje más elevado de acciones es propiedad de nacionales; es decir, aunque la inversión es fundamentalmente nacional, la gestión es de compañías extranjeras. ${ }^{23}$ Según el Plan Nacional de Turismo, en Acapulco manejan $55 \%$ de los cuartos de las tres primeras categorías de hospedaje. ${ }^{24}$ Las cadenas internacionales más importantes que operan en el puerto son: Continental Hilton, Hyatt International, Príncess Hotel International, Western International Hotels, Sheraton, Holiday Inn, Marriot, Melia, etc.; varias de ellas se encuentran asociadas con lineas aéreas como Transworld Airlines, Braniff International, Canadian Pacific, American Airlines, etc. Estas empresas extranjeras "por la modernidad de sus métodos de planeación y administración, por sus capacidades publicitarias en todo el mundo, por su aptitud en el manejo del mercado, poseen una dinámica que las hace obtener altas ganancias aprovechando la infraestructura creada por el ahorro público". ${ }^{25}$

La inversión realizada directamente en la construcción de hoteles incrementó de manera notable la capacidad de alojamiento turístico de Acapulco. De 1960 a 1971 el total de cuartos construidos,

${ }^{20}$ Cazes, G., op. eit., p. 131

21 Uno más Uno, 18 de noviembre de 1981, editorial.

22 Moreno T, O., "La estructura internacional del negocio turistico" en Comercio Exterior, núm. 3, marzo, 1970, pp. 250 y 251, y Navarrete, J.E., "El turismo y la economia de los paises en desarrollo", en Comercio Exterior, núm. 7, julio, 1971, p. 37.

23 Secretaria de Turismo: Plan Nacional de Turismo, México, 1979, p. 203.

24 Igual a nota 23, y Cazes, G., op. cit., p. 122.

25 Uno más Uno, 18 de noviembre de 1981, editorial. 
considerando las cinco categorías de hoteles, fue de 7685 . El número de cuartos de la categoría I o de lujo aumentó diez veces, mientras que las categorías restantes, y en particular la popular, simplemente se duplicaron en el periodo en cuestión (cuadro 3). Ello indica una clara tendencia a favorecer el turismo destinado a sectores minoritarios del país y del vacacionista extranjero, en particular, del norteamericano. Por su parte, las dos primeras categorías de hoteles disponen de $48 \%$ de los cuartos existentes; es decir, como en otros sectores de la economía, se observa un proceso creciente de concentración. Obviamente ésta es mayor en el caso de las cadenas hoteleras, complejos y conglomerados extranje ros a los que se acaba de hacer alusión; significa que de la fase de concentración se estaba pasando ya a la de oligopolización.

CUNDRO 3

Desarrollo del número de cuartos, según categoría de hoteles, en Acapulco

\begin{tabular}{llllllr}
\hline Ano & $I$ & $I I$ & $I I I$ & $I V$ & $V$ & Total \\
\hline 1960 & 312 & 1426 & 964 & 1032 & 960 & 4694 \\
1961 & 315 & 1426 & 968 & 1184 & 1076 & 4969 \\
1962 & 544 & 1476 & 1040 & 1286 & 1128 & 5474 \\
1963 & 640 & 1491 & 1125 & 1370 & 1189 & 5825 \\
1964 & 806 & 1559 & 1145 & 1479 & 1257 & 6.246 \\
1965 & 806 & 1569 & 1234 & 1566 & 1336 & 6511 \\
1966 & 810 & 1622 & 1336 & 1660 & 1442 & 6870 \\
1967 & 810 & 1643 & 1615 & 1842 & 1554 & 7464 \\
1968 & 181 & 1741 & 2082 & 2051 & 1803 & 8858 \\
1969 & 1623 & 1812 & 2228 & 2144 & 1860 & 9667 \\
1970 & 1828 & 2062 & 2291 & 2212 & 1860 & 10253 \\
1971 & 3805 & 2136 & 2351 & 2227 & 1880 & 12379
\end{tabular}

Tasa de crecimicnto anual (\%)

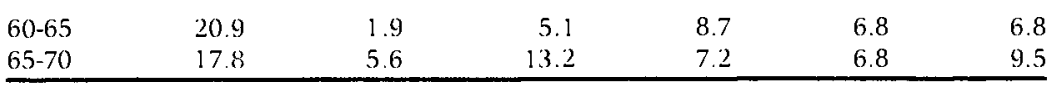

Fuente: INFratur.

Por otra parte, a través de otras fuentes se sabe que el número promedio de cuartos de un hotel independiente es de 28 , mientras que en el caso de las cadenas mexicanas es de 131 y el de las extranjeras asciende a 308. Estas últimas disponen de un poder amplio en la actividad turística local, ${ }^{26}$ pero los centros de decisión de estas

26 Cazes, G., op. cit., 127. 
compañías transnacionales se ubican fuera del país, de tal manera que, bajo este aspecto, se trata de una actividad económica desnacionalizada. Visto el fenómeno desde el ángulo de los pequeños y medianos hoteleros, ello significa una clara posición de desventaja que se traduce en un acceso desigual al recurso financiero. ${ }^{27}$

Durante el periodo 1960-1971, la tasa de crecimiento anual de cuartos fue desigual pero, en conjunto, acusó una tendencia creciente entre las categorías y quinquenios del periodo. Considerando globalmente ambos elementos, la tasa promedio para dicho lapso fue $8.5 \%$, porcentaje superior al observado tanto a nivel nacional como mundial. En otros términos, la dinámica hotelera de Acapulco tuvo un comportamiento excepcional; esta tendencia fue particularmente importante durante el lapso 1969-1971 en el que entran en servicio varios hoteles de gran capacidad. ${ }^{28}$

El fenómeno registrado en el número de cuartos de hotel se observa también en la construcción de condominios, a partir de 1964. De esa fecha a 1973, su capacidad pasó de 195 cuartos a 2282 , y a 4378 en 1975. En este último año, el número de edificios en condominios ascendia a $39 .{ }^{29}$ Éstos se hallan vinculados a grandes hoteles que aseguran frecuentemente su gestión. Bajo el mismo criterio de exclusividad o turismo de lujo, se construyeron "villas" y bungalows que se rentaban a tarifas del orden de 150 a 500 dólares por día en $1976 .{ }^{30}$

Paralelamente al incremento de hoteles y cuartos, fueron aumentando los flujos turísticos. En 1954 los visitantes del puerto fueron $92694 .^{31}$ En 1960, éstos habian aumentado a 540 100, es decir, seis veces en relación a 1954. Este acelerado crecimiento se mantiene hasta 1972 en que se eleva a 1.5 millones. ${ }^{32}$ Estas cifras son tanto más significativas cuanto que no incluyen turistas que pasan los fines de semana o las vacaciones en casas habitación, departamentos (condominios), bungalows y villas propias o rentadas.

Del total de turistas que arriban a Acapulco, el flujo de naciona-

27 Esta situación se repite también ahora. Recientemente, los representantes de los 200 hoteles asentados en el Acapulco tradicional o zona antigua de la ciudad de Acapulco se han quejado por la falta de créditos y por los requerimien tos y obstáculos que se presentan para otorgárselos (24 de junio de 1985). Al respecto, véase la declaración de FONATUR según la cual autorizaría en 1985 préstamos por 40500 millones de pesos para 7000 cuartos nuevos y 2500 remozados. Uno más Uno, 5 de julio, 1985.

28 Gormsen, E., op. cit. p. 40.

29 INFRATUR, op cit., p. 8.

${ }^{0}$ Cazes, G., op. cit., pp. 127 y 209.

31 Gorsmcn, E., op. cit, p. 38.

32 INFRATL'R, op. cit., pp. 5 y 7. 
les fue superior al de extranjeros durante el periodo en cuestión (55\% y $44 \%$, respectivamente) y de estos últimos la mayor parte arribó por vía aérea. De acuerdo a los datos de la Secretaría de Turismo (SECTUR), la estancia promedio de los visitantes de origen nacional es de 2.9 días y la de extranjeros $5.7 .{ }^{33} \mathrm{Y}$ a medida que aumentaban los flujos turísticos fueron perdiendo selectividad: Acapulco se masificaba, particularmente en la temporada alta (Semana Santa).

La importancia que la actividad turística tiene para la economía del país y, en particular, para la región acapulqueña es indudable. Hasta 1979, el turismo superaba al petróleo en la captación de divisas; en esa fecha, la relación era de 101433 y 87157 millones de pesos respectivamente. En ese total, la participación de Acapulco era significativa ya que representaba $42 \%$, es decir, casi la mitad de los ingresos totales que el país recibía en el renglón turístico. ${ }^{34} \mathrm{Ob}$ viamente esta relación se modificó con el auge petrolero de 1979-1981, pasando a ser el turismo la segunda fuente generadora de divisas.

En cuanto a los ingresos fiscales originados por las diversas tasas turísticas, aquéllos representaron, a nivel nacional, 3582 millones de pesos en 1965 y 4437 en 1967, es decir $9.98 \%$ y $11.5 \%$ del total de las entradas fiscales del país. Por lo que se refiere a Acapulco, en 1964 el turismo aportaba $40 \%$ de las rentas fiscales del estado de Guerrero, con un monto del orden de 40 millones de pesos. ${ }^{35}$

Para dimensionar en su justa magnitud estas cifras, habria que restarles no sólo las salidas por concepto de turismo egresivo (nacionales que visitan como turistas otros países) sino otro tipo de egresos que no son explicitados por las estadísticas oficiales de este sector. Por lo que se refiere al turismo de zonas costeras económicamente débiles y en las cuales se instalan complejos turísticos que responden al modelo internacional, (como es el caso de Acapulco), el recurso a las importaciones y los pagos efectuados por concepto de contratos de gestión o de concesiones hoteleras es alto. $\mathrm{O}$. Moreno $\mathrm{T}$, de acuerdo con la información disponible, estima que si se considerara la totalidad de estos gastos (directos e indirectos), habria que reconocer la existencia de un déficit neto en el sector turístico del país. ${ }^{36}$

En cuanto a la capacidad generadora de empleo del sector turís-

33 SECTUR, "Estudio sobre la actividad turistica en Acapulco", agosto, 1983, p. 20.

34 Fideicomiso de Acapulco (FIDACA), Plan de Acciones Básicas 1980-1982, MéxiCo, Imprenta Venecia, tomo II, 1981, p. 40.

${ }_{35}$ Ochoa Campos, M., Guerrero: Análisis de un estado problema, México, 1964, p. 105.

36 Moreno T., O., op. cit., p. 247. 
tico, ésta es importante. En el caso de Acapulco, el número de ocupados en él asciende a 20000 de base; el resto obtiene sólo ocupación temporal. Sin embargo, esta oferta de empleo no es suficiente ni para la población nativa ni para los migrantes. Ello evidencia que si bien la actividad turística seguirá siendo la más importante en Acapulco, urge diversificar la base económica del puerto, porque ya no puede depender exclusivamente de la primera. Obviamente debe garantizarse que las nuevas fuentes de empleo que se generen no afecten el medio ambiente de la bahía.

\subsection{Una estructura urbana desarticulada}

Las transformaciones a que se vio sometida la ciudad de Acapulco en el periodo anterior adquirieron dimensiones insospechadas de 1955 a 1971. La mancha urbana aumenta considerablemente de extensión tanto por el incremento del número de hoteles y fraccionamientos como por el surgimiento de colonias populares. Se construyen avenidas; se zonifican sectores residenciales, y se suple parcialmente la insuficiencia de equipamiento urbano.

En los años cincuenta se amplía la vialidad. En el distrito interior de la ciudad se renueva el alumbrado y se edifican comercios y restaurantes como Woolworth y Sanborns. Durante la presidencia de Gustavo Diaz Ordaz (1964-1970), se intenta, sin lograr resultados significativos, remodelar el viejo casco de la ciudad. Las transnacionales hoteleras y las tiendas turisticas de alta calidad se instalan principalmente sobre la Avenida Costera. La estructura fundamental de la ciudad viene dada por un solo centro, una vía única principal de circulación (La Costera) y por tres sectores básicos. ${ }^{37}$

Los sectores son:

a) de carácter exclusivamente turístico, por ejemplo, la Península de las Playas, la zona costera o corredor que bordea las playas de la bahía y posteriormente de Puerto Marqués, Revolcadero y Pie de la Cuesta;

b) de tipo mixto, es decir, que contiene servicios urbanos que apoyan tanto el turismo como las diferentes actividades urbanas; centro cívico y comercial, y

c) de índole habitacional, tanto residencial como popular.

Las áreas planas de la ciudad contienen el viejo centro urbano y gran parte de la zona turística. El viejo centro desempeña funciones comerciales, administrativas y políticas, así como habitaciona-

\footnotetext{
"Gormsen, E., op cit., p. 47; Gómejjara, F., "Acapulco, el paraiso perdido", mp cit., p. 107 y Conde G., N., op. cit., pp. 24 y 67.
} 
les para la pequeña burguesía y parte de la clase trabajadora. Detrás de estas áreas planas, se elevan los cerros donde se asientan, de manera progresiva, colonias populares.

La estructura primaria y débil de la ciudad es evidenciada por la carencia de reservas territoriales, el déficit de vivienda y la insuficiencia de las infraestructuras, servicios y equipamiento urbano. $\mathrm{Si}$ bien estas limitantes afectan incluso a la actividad turistica, es notorio el acceso desigual que la población tiene a los servicios existentes en relación a los vacacionistas. Un rápido análisis así lo manifiesta.

2.2.1. Vivienda. En 1985, el déficit acumulado de vivienda asciende a 26000 , al que se agregan 10000 más cada año. Por otra parte, $15 \%$ de las viviendas existentes no dispone de energía eléctrica. Junto con la ausencia de reservas territoriales, la escasa cobertura de los programas públicos de vivienda de interés social explican las invasiones de tierra y el surgimiento de colonias populares en las que vive más de la mitad de la población total.

2.2.2. Abastecimiento de agua. Si aparentemente la captación de agua no presenta problemas, Acapulco afronta serias dificultades en su distribución por la reducida extensión de la red hidráulica. De las viviendas, 58\% carece de instalación de agua dentro de ellas en franco contraste con el líquido utilizado por los vacacionistas.

2.2.3. Drenaje. Casi la mitad (44.5\%) de las viviendas carece de drenaje. Y, a pesar de las obras realizadas, todavía existen hoteles que descargan directamente las aguas negras a la playa. Por otra parte, la ciudad todavia no cuenta con una planta de tratamiento de las aguas residuales a nivel secundario.

2.2.4. Vialidad y transporte. Tanto el área de la vialidad como de los estacionamientos es insuficiente para el parque automotor existente. El aeropuerto internacional y la nueva central camionera cubren apenas los requerimientos actuales. El transporte interurbano no satisface las necesidades de los pasajeros y provoca congestionamientos y contaminación atmosférica.

2.2.5. Mercados. A pesar de su importancia urbana, Acapulco no cuenta con una central de abastos, sino tan sólo con un mercado al mayoreo. El actual sistema de comercialización de productos perecederos es insuficiente, costoso e insalubre.

2.2.6. Otros servicios. La ciudad carece de alumbrado suficiente incluso en lugares céntricos. El servicio de recolección de basura cs muy deficiente. Más de la mitad de la población carece de atención médica regular.

El resultado de la distribución desarticulada de espacios, y de la dotación insuficiente de los elementos urbanos mencionados es una estructura urbana débil y poco funcional. 
3. El estancamiento, la contaminación y la aplicación de medidas correctivas: 1972-1985.

En este periodo, Acapulco va perdiendo importancia como centro turístico y su contaminación ambiental se agudiza, logrando corregirla sólo parcialmente.

\subsection{Las oscilaciones de la oferta de cuartos y del flujo turístico}

El crecimiento en el número de cuartos, detectado en el periodo anterior, se mantuvo hasta 1972. La oferta creció ese año en 3728 en términos absolutos y 33.7 en porcentuales; este comportamiento no vuelve a repetirse en la década siguiente (cuadro 4). El repunte de la oferta hotelera en 1979 parece deberse más a factores macroeconómicos nacionales (auge petrolero) que a las tendencias propias de la dinámica de Acapulco. Este aumento aislado en el periodo sufre un reflujo rápidamente, como resultado de la crisis económica en que entra el país.

El incremento registrado entre 1971 y 1972 es probable que se haya generado de una inversión fuerte del Estado en infraestructura hotelera. El pronunciamiento que hizo Luis Echeverria A., en apoyo a la refuncionalización de Acapulco, refuerza esta interpretación. ${ }^{38}$ Considerado en conjunto el periodo y a pesar de las oscilaciones en la variación (absoluta y relativa) de cuartos, puede afirmarse que la actividad turística estaba creciendo ya de manera muy lenta y mostrando signos de estancamiento. Estos fenómenos pueden estar causados por los informes sobre la contaminación de la bahía, los cuales pudieron poner en guardia a los inversionistas. Asimismo, otra de las razones estriba en la canalización de recursos hacia otros centros turísticos extranjeros por parte de las trasnacionales que operan en esta rama económica. Como es sabido, "la rivalidad entre los países del mundo por atraer cada vez mayores contingentes de visitantes se agudiza cada dia"39 y afecta a las estaciones turísticas existentes. Esta situación también se da a nivel nacional con la asignación de inversiones en nuevos puntos del país que gozan de estímulos durante su primera fase de evolución (exenciones, subsidios, etc.) y no hacen competitiva la inversión para nuevos hoteles en Acapulco.

38 "La afluencia turística, el desarrollo anárquico y el vertiginoso crecimiento demográfico de Acapulco son factores que han sido el origen de numerosos problemas que debemos enfrentar para resolverlos lo más rápidamente posible". (L. Echeverría A., marzo, 1970).

39 Gormsen, E. op cit., 38 . 


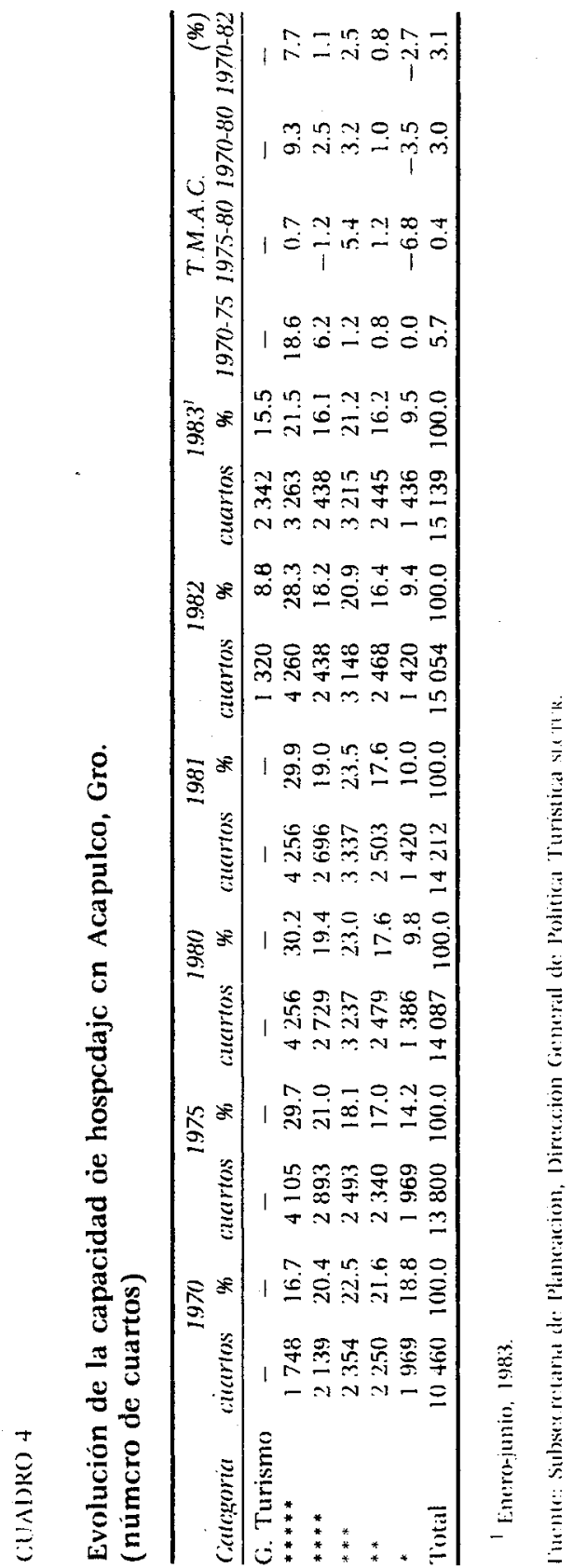


La afluencia de turistas tanto nacionales como extranjeros también disminuye en el periodo considerado, sobre todo en el lapso 1974-1982 (cuadro 5). La tendencia descendente que acusa el flujo turístico en Acapulco no es atribuible a la crisis interna del país ni al estancamiento de la economía mundial, ya que, en el mismo periodo, la afluencia turística registra un incremento a nivel nacional. ${ }^{40}$ Esta disminución se agudiza en el lapso 1977-1981, cuando la tasa anual correspondiente aumenta significativamente para el país en su conjunto. Este fenómeno no puede ser asociado a la campaña de desprestigio que la comunidad judía norteamericana desató contra el país en 1975 y tampoco puede relacionarse con las presiones recientes hacia México por parte del gobierno norteamericano. Ciertamente, con motivo de ambos hechos, viajeros de EE.UU. (que representan la mayor parte del turismo receptivo) cancelaron reservaciones hacia México. Pero estas medidas afectaron a la actividad turística del país y no especialmente a Acapulco. Igual argumentación hay que aplicar a la repercusión que la inflación está teniendo en el turismo receptivo.

\section{CUADRO 5}

Afluencia del turismo receptivo a Acapulco

\begin{tabular}{|c|c|c|c|}
\hline$A \tilde{n} o$ & $\begin{array}{c}\text { Total de turistas } \\
\text { en el pais, comiente } \\
\text { efectiva }\end{array}$ & $\begin{array}{c}\text { Total de turistas } \\
\text { en Acapulco, con } \\
\text { pernotita }\end{array}$ & $\begin{array}{l}\% \text { sobre } \\
\text { detatal }\end{array}$ \\
\hline 1972 & 2914593 & 651918 & 22.4 \\
\hline 1973 & 3226398 & 704877 & 21.8 \\
\hline 1974 & 3362247 & 73229.3 & 21.8 \\
\hline 1975 & 3217884 & $63087 \%$ & 19.6 \\
\hline 1976 & 3107003 & 639219 & 2016 \\
\hline 1977 & 3247055 & 73271.5 & 22.6 \\
\hline 1978 & 3753853 & 675275 & 18.0 \\
\hline 1979 & 4134186 & 652363 & 15.8 \\
\hline 1980 & 4144249 & 569579 & $13 \%$ \\
\hline 1981 & 4031432 & 487966 & 12.1 \\
\hline
\end{tabular}

Fucnte: Encuestas Banco de: Mixico.

Elaboro: Instituto Mexicano de Investigaciones Turisticas

40 Según declaración del Secretario de Turismo, la evolución del turismo receptivo de México fue durante 15 años más dinámica que la mundial, pues registró un promedio de crecimiento de $5 \%$ anual, al pasar de 2 millones 250 mil visitantes en 1970 a 4 millones 700 mil en 1984. Uno más Uno, 17 de junio de 1985

Véase sectur. "Estadísticas Básicas de la Actividad Turística", 1984. p. 11 
En cuanto al turismo interno, se observa un estancamiento en niveles bajos debido al deterioro del poder adquisitivo y a cambios en las pautas de viaje en favor de lugares distintos a los de la playa, afectando a todos los centros marítimos. ${ }^{41}$

Por otra parte, los promedios de ocupación registrados en los hoteles de Acapulco se caracterizaron por mantener un nivel modesto que fluctuó entre 50 y $65 \%$ en el perido 1970-1982; en particular, a partir de 1979 la ocupación presenta un descenso continuo. Esta tendencia no sufrirá variaciones importantes en los dos próximos años. Por ello, a pesar de que siga siendo el centro turístico más importante del país, las tendencias observadas en la construcción de nuevos cuartos y la afluencia de turistas demuestran que Acapulco está perdiendo importancia a nivel nacional e internacional.

\subsection{La contaminación de la bahía: un secreto a voces}

Para el turismo, especialmente en los centros vacacionales de playa, los recursos naturales y el medio ambiente son su plataforma natural, su medio básico de operación; es decir, "el quehacer turístico gira alrededor de la explotación de los atractivos naturales y no puede, como algunas ramas industriales, prosperar sobre la base de ecosistemas destruidos"; por el contrario, "el espacio turístico debe reunir requisitos de alta compenetración con los ecosistemas naturales... y lograr la integración de la estructura ecológica que lo compone, de la estructura urbana y de la estructura conductual, es decir, del comportamiento social". 42

Por lo que se refiere a Acapulco, era decisivo, antes de impulsar su desarrollo turístico, partir de un conocimiento preciso de las condiciones del medio, es decir, las características del emplazamiento (marco físico) y del comportamiento de las corrientes en la bahía.

\subsubsection{Las características del medio natural ${ }^{43}$}

La bahía posee la forma y disposición de un anfiteatro y está rodeada por un macizo montañoso que ocupa el lugar de las gradas

4) Banco Nacional de México, Informe sobre turismo, marzo 1985, y participación en la Cuarta Reunión de Financiamien to a las Actividades Turísticas, 4 de julio de 1985

${ }_{42}$ Molina, S., "Turismo y ecología", edit. Trillas, México, 1983. p. 5. Más adelante precisa este autor: "en la actividad turística, el aspecto ecológico es comparativamente más importante que la posición que podría tener en la mayoría de los restantes quehaceres económicos", p. 45.

43 La información de este apartado fue tomada básicamente de la Secretaría de Desarrollo Urbano y Ecología, y Secretaría de Marina: ver trabajos citados en Biblio- 
y presenta fuertes pendientes que oscilan entre 36 y $70 \%$ en sus laderas sur y suroeste. En la región costera, bajando de las partes altas del macizo, existen siete cuencas hidrográficas y escorrentias que están dispuestas radialmente con el centro de la bahía como eje; es decir, la bahía viene a ser la parte central y más baja del anfiteatro y funciona como cuenca de depósito y receptáculo de los materiales que se acumulan en las partes altas que circundan el anfiteatro. La fuerte pendiente de sus laderas y su deficiente vegetación, así como las condiciones meteorológicas de la zona (largos periodos de sequía con elevadas temperaturas, seguidos por periodos de precipitaciones intensas y concentradas) constituyen la causa principal del transporte de tierra y desechos sólidos hacia la bahía. Ésta conforma una cuenca semicerrada y las aguas cuentan con poca profundidad; constituyen un cuerpo pequeño de agua y su volumen es aproximadamente $357000000 \mathrm{de}^{3}$, comparable al de un pequeño lago. Por otra parte, las corrientes no poseen la magnitud y dirección adecuadas para distribuir y sacar a mar abierto los sólidos y material de origen continental que llegan a la bahía. Debido a esta escasa circulación del agua, su recambio o renovación es lento, tardando en algunas áreas tres años en renovarse, sobre todo en las zonas de Club de Yates, Hornos y Caletilla. Ambos fenómenos reducen el radio de acción de las descargas y provocan que la concentración de materiales en el interior de la bahía alcance niveles altos y se acumulen casi a la boca de las descargas. Estas características del medio natural condicionaban el uso del suelo (habitacional, áreas verdes, etc.) y establecían de antemano posibles puntos de conflicto ambiental.

\subsubsection{Agentes contaminantes y grado de contaminación ${ }^{44}$}

El medio ambiente de Acapulco ha sido alterado en su atmósfera y en sus aguas. La contaminación atmosférica es provocada por los gases y ruido que emiten los vehículos, públicos y privados, tanto de transporte de carga como de pasajeros, asi como por la planta cementera que se encuentra a la entrada del puerto. ${ }^{45} \mathrm{La}$ alteración de las aguas existe a dos niveles: la del agua potable y la de las aguas salinas de la bahía. La empresa Celulosa del Pacífico, cuyas instalaciones se ubican en Tierra Colorada, contamina con desechos quí-

grafia, y Movimiento Ecologista Mexicano: "Acapulco grave riesgo", estudio presentado en el hotel Camino Real de Acapulco, el 25 de febrero de 1985.

44 Además de los estudios aludidos en la nota anterior, para la elaboración de este inciso se utilizaron los trabajos de la SARH citados en la Bibliografía.

45 Véase Plan Contingente Acapulco, op. cit., pp. 2 y 3. 
micos las aguas del río Papagayo del cual se suministra el líquido a la población del puerto. ${ }^{46}$ Por su grado de contaminación y la repercusión consiguiente en la actividad económica fundamental de Acapulco, es particularmente importante la polución de las aguas de la playa. Desde mediados de la década de los años sesenta, era ya de dominio público la contaminación de las aguas de la bahía. Pero, como ha sucedido en otros países y frente a diferentes problemas ambientales, inicialmente se optó por negar los hechos y desconocer responsabilidades. Sin embargo, a partir del reconocimiento público que hizo en 1970 L. Echeverría sobre la situación prevaleciente, se realizaron varios estudios sobre el deterioro del medio ambiente. Considerando en conjunto dichos estudios, los agentes contaminantes son:

a) Aguas negras o residuales

Las descargas ilegales de aguas negras tanto de hoteles como viviendas (residenciales o populares) se estaban efectuando de manera directa a la bahía, es decir, sin tratamiento previo. Estas fuentes municipales, turísticas y domésticas, son el factor básico de contaminación de las aguas salinas; a ellas hay que agregar las descargas de aguas residuales que realizan las embarcaciones (barcos de pasajeros y de carga, yates, etcétera).

b) Basuras $y$ desperdicios

Proviniendo de las mismas fuentes (hoteles, viviendas y embarcaciones) y arrastrados por las lluvias o arrojados por la población residente o los turistas, grandes cantidades de desechos sólidos llegan hasta la bahía; permanecen suspendidos algún tiempo en las aguas $\mathrm{y}$, en su mayoría, terminan sedimentándose.

c) Aceites, grasas y petróleo

La base naval de la marina, el muelle de PEMEX y las embarcaciones tanto turísticas o deportivas como de carga, y los talleres vierten sobre las aguas estos contaminantes que permanecen largo tiempo sin degradarse y no son expulsados por permanecer en áreas (Club de Yates, base naval y muelle de PEMEX) en las cuales la renovación del agua es muy lenta.

d) Pesticidas $e$ insecticidas

Debido a las campañas que realiza el Consejo Nacional de la Secretaría de Salubridad y Asistencia para la Erradicación Palúdica, el anfiteatro de la bahía ha sido sometido a intensos rociados de DDT, desde 1957. Esta substancia posee extrema toxicidad y prolongada persistencia en el medio; los residuos son arrastrados por las lluvias

th Vease declaración a la prensa del alcalde del puerto, 19 de junio de 1985. 
y van a depositarse en las aguas salinas. Aunque las concentraciones no son muy elevadas, se requieren largos periodos para que sean degradadas.

e) Erosión y deforestación

Los agentes naturales (clima, viento, lluvia, etc.) y la urbanización incontrolada (tanto por la implantación de hoteles como de residencias y vivienda popular) están eliminando grandes áreas vegetales que funcionaban como tapete conservador de los suelos. La falta de protección provoca que los torrentes acarreen los materiales erosionados a la bahía.

Después de cincuenta y ocho años de actividad turística, hoy es posible afirmar que las causas del deterioro ambiental no fueron adecuadamente encauzadas y que los efectos son innegables: la calidad de las aguas ha sido alterada y existe objetivamente contaminación en ellas. Evidentemente su grado y nivel de deterioro están relacionados con el uso al que se pretenda someterlas. De los diferentes usos posibles, es claro que en un balneario de playa predomina el turístico o recreación con contacto primario. Este puede asumir varias modalidades relacionadas con la natación y otros deportes acuáticos (buceo, esquí, etc.) que requieren contacto con el cuerpo, a unque no deben ser descartadas la pesca y vida acuática.

La determinación del grado de alteración de las aguas salinas se halla también supeditada a los criterios y reglamentos que para este fin se apliquen. En el caso de México, se remite al "Reglamento para la Prevención y Control de la Contaminación de las Aguas", aprobado en 1973 (curiosamente años después de que se hubiera detectado la existencia de contaminantes en las playas de Acapulco...). De los criterios utilizados en este reglamento la Secretaría de Asentamientos y Recursos Humanos (SARH) aplica, en particular, los que establece la tabla 6 clase II; éstos son:

a) Se puede tolerar que uno de los muestreos mensuales sobrepase el número más probable (NMP) 1000 coliformes $/ 100 \mathrm{mi}$., siempre que no sobrepase el NMP $10000 / 100 \mathrm{mi}$., y

b) Se debe considerar por encima de la norma de seguridad (es decir, como contaminada) toda estación que muestre dos o más valores mensuales superiores a NMP 1000, o cualquier estación que muestre por lo menos 1 valor superior a NMP $10000 .{ }^{47}$

\footnotetext{
t' Debe resaltarse que los criterios utilizados por la sikll se centran en el análisis de los coliformes (totales y fecales). A fin de determinar el índice de calidad del agua, otros autores proponen criterios adicionales; como: a) cantidad de materia orgánica presente: Oxígeno disuelto (OD) y Demanda Bioquímica de Oxígeno (DBO) y b) cantidad de materia iónica presente, entre la que destacan el potencial de hidró-
} 
A fin de verificar el estado de las aguas de la bahía de Acapulco se seleccionaron 14 estaciones de monitoreo de 1976 a 1978 y 17 de 1979 a 1982 (cuadro 6). Los resultados de los análisis realizados hasta 1982 fueron: "la calidad sanitaria de las playas de la bahía de Acapulco en cada mes sobrepasa la norma fijada por el reglamento vigente ${ }^{\prime \prime}{ }^{48} \mathrm{La}$ contaminación era tan manifiesta que la Organización Mundial de la Salud (oms) de la onv y la Oficina Sanitaria Panamericana estaban dispuestas a aplicar medidas internacionales estrictas.

Por lo que se refiere a las grasas y aceites, sus niveles no sobrepasan los límites tolerables. Y en lo relativo a los detergentes, su contenido se puede considerar normal en este tipo de desecho. ${ }^{49}$

En cuanto a los turistas, se incrementaban los informes sobre enfermedades gastrointestinales, de la piel y de los ojos causadas por el contacto con agua. ${ }^{50} \mathrm{El}$ con trasentido que implica esta situación era manifesto: el turista se desplaza a Acapulco en busca de sus playas y aguas, pero la contaminación le impedía nadar en ellas, incluso realizar cualquier deporte que requiera introducirse en el agua, salvo con el riesgo de contraer una enfermedad.

El impacto en los recursos marinos (flora y fauna acuática) era también notable. La bahía de Acapulco "cuenta con una rica variedad de especies marinas cuya explotación racional bastaría para abastecer sin problemas el consumo del puerto, en lo que a estos pro-

geno $(\mathrm{pH})$, grasas y aceites, sólidos suspendidos, sólidos disueltos, nutrientes y detergentes. Véase, al respecto, J.L. Calderón B. "Indice de calidad del agua", ponencia presentada en el XVII Congreso Interamericano de Ingeniería Sanitaria y Ambiental, julio de 1980, La Paz, Bolivia.

Coliformes totales expresa la cantidad de bacterias suspendidas y es un índice de gran importancia para determinar la calidad sanitaria de los cuerpos de agua.

Coliformes fecales expresa las bacterias patógenas del grupo e.coli. las cuales se originan principalmente en el intestino grueso del hombre. La presencia de e.coli, es por tanto, un indicador claro de contaminación fecal.

${ }^{48}$ Dr. Aguirre M., J., Ing. J.L. Calderón B. e Ing. F. Bahamonde I: "Diagnóstico y solución a la problemática de la contaminación del agua, Estado de Guerrero", PRIIEPES-CEPES, noviembre 1981, p. 23. De acuerdo con el análisis realizado por la Dirección General de Prevención de la Contaminación del agua de la SEDUE, "La calidad bacteriológica relativa al porcentaje de los muestreos (en la bahía de Acapulco) de los años 1981-1982 muestra que la estación sobrepasó el límite del reglamento. "Informe sobre la bahía de Acapulco. 1985, mimeo, p. 8.

49 Rodríguez G., S. y L. Quezada C: "Solución al problema de contaminación por descargas de aguas residuales a la bahía de Acapulco", ponencia presentada en el III Congreso Nacional de Ingeniería Sanitaria y Ambiental, septiembre 1982, p. 6.

50 SAHOP "Ecoplan del Municipio de Acapulco", 1981, p. 133. sECTuR. "La contaminación de las aguas de la bahía de Acapulco y su impacto en el desarrollo turísti$\mathrm{co}^{\prime \prime}, \mathrm{s} / \mathrm{f}$ mimeo, p. 4 


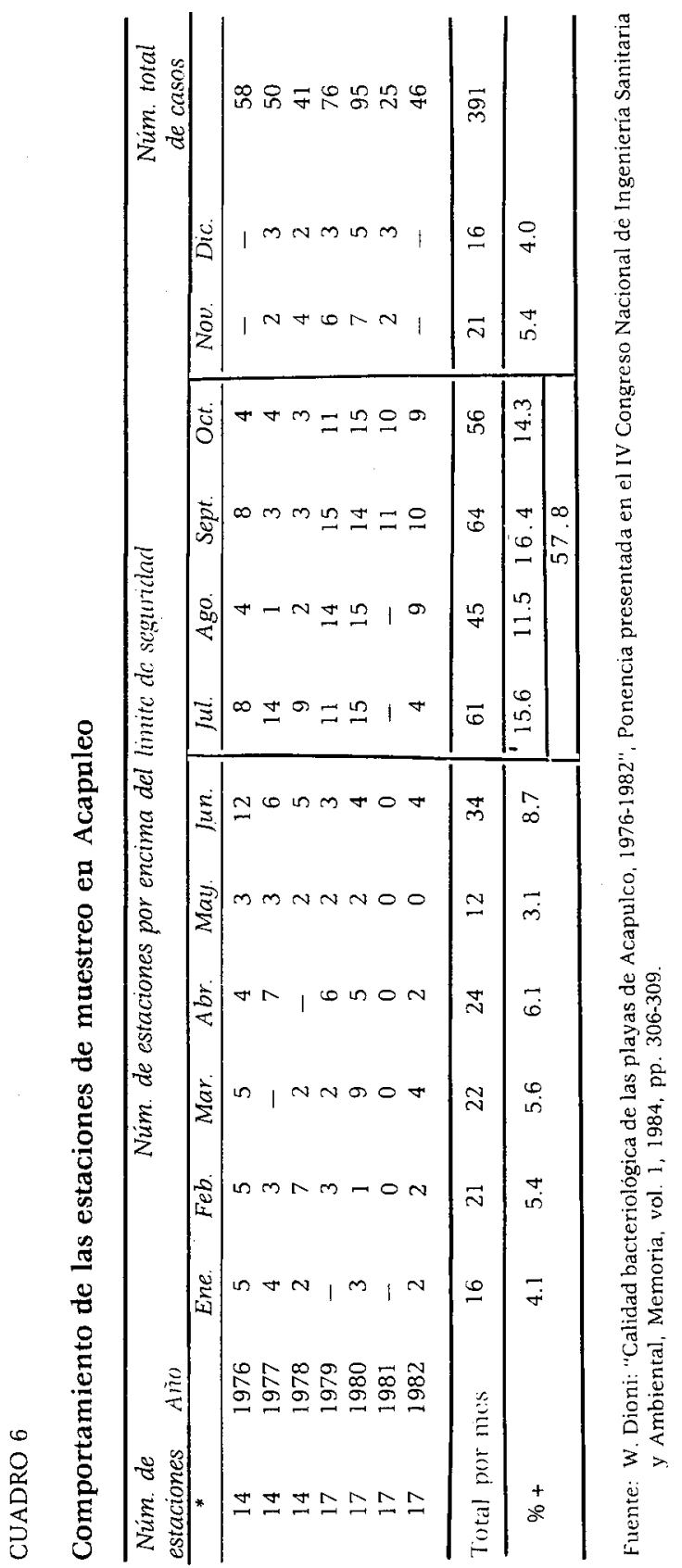


Porcentaje de transgresiones al reglamento

\begin{tabular}{|c|c|c|}
\hline$\%$ & $\begin{array}{l}\text { Nim de } \\
\text { playas }\end{array}$ & Playas \\
\hline 0 & 2 & La Roqueta, Icacos Sur \\
\hline $10^{*}$ & 4 & $\begin{array}{l}\text { Caleta, Club de Yates, Condesa, } \\
\text { Icacos Norte. }\end{array}$ \\
\hline $11-15$ & 6 & $\begin{array}{l}\text { Hornitos, Playa Larga, Tlacopanocha, Hornos, Papagayo, } \\
\text { Costa Azul }\end{array}$ \\
\hline $16-20$ & 0 & \\
\hline $21-25$ & 3 & Ensenada de los Presos, Playa Honda, P. A. Magallanes \\
\hline $26-30$ & ! & Caletilla \\
\hline 30 & 1 & La Garita \\
\hline
\end{tabular}

* Todas las playas de la bahja de Puerto Marques, y la playa de la Langosta, ubicada fuera de la bahia, pertenecen a esta categoria.

Fuente: W. Dioni: "Calidad bacteriológica de: las playas de: Acapulco, 1976-1982", ponencia presentada en el IV Congreso Nacional de Ingenieria Sanitaria y Ambiental, Memoria, vol. I. 1984, pp. 306-309

ductos se refiere, y evitaría que éste dependiera, para su abastecimiento, de otras localidades o regiones". ${ }^{1}$ Sin embargo, los rendimientos de la pesca tanto en el municipio de Acapulco como en los que integran la región han disminuido debido á que el hábitat de las especies marinas está siendo deteriorado por los desechos que se arrojan y las descargas de aguas negras.

En síntesis, la alteración de la calidad de las aguas salinas, afectó al medio ambiente y, como consecuencia, a la actividad turística, a los vacacionistas, a la propia ciudad.

A través de las entrevistas que en 1985 realicé a funcionarios de varias secretarías implicadas, se infiere que a partir de 1982:

- han disminuido levemente los niveles de contaminación, pero la situación básica subsiste; 52

- en el corto plazo, el gobierno no realizará nuevas obras que mejoren substancialmente el estado actual de las aguas de la bahía; ${ }^{53}$

5! Rodriguez, S. y L. Quezada, op. cit., p. 3.

52 El "Programa Nacional de Ecologia, 1984-1988" afirma: "La contaminación de las aguas estuarinas y marinas es especialmente notable en las áreas más importantes por su potencial comercial, pesquero y turistico. Tales son los casos de Acapulco, Salina Cruz, Lázaro Cárdenas, Veracruz, Can-Cún y La Paz", p. 34.

${ }^{5.3}$ El "Programa Nacional de Turismo; 1984-1988" incluye, en las metas de resultado y previsión de recursos para 1984, únicamente el compromiso de "promover la remodelación de la oferta de hospedaje en la zona tradicional de Acapulco" p. 76. 
- la mayoría de los hoteles ha conectado sus drenajes al colector de la Costera; algunos cuentan con pequeñas plantas de tratamiento primario de las aguas negras que permiten su reuso;

- persisten las descargas clandestinas de aguas negras a la bahía, por parte de algunos hoteles y zonas de habitación popular y residencial;

- a veces falla el sistema de drenaje, es decir, se azolva y las descargas se vierten al mar. La planta de tratamiento no se ha construido aún;

- la zona del anfiteatro se está poblando de nuevo; debido a la carencia de drenaje, ello aumenta el fecalismo al aire libre y el arrastre de residuos a la bahía.

\subsection{La planificación de Acapulco, o las acciones emprendidas... y} las pendientes

Acapulco no es el resultado de una planeación inductiva o preventiva. A partir de este hecho, se atribuyen todos los conflictos del puerto (sociales, ecológicos, urbanos y específicamente turísticos) a la ausencia de un plan que normara su crecimiento. Sin embargo, en 1945 se constituyó la Junta Federal de Mejoras Materiales y se formuló el primer plano regulador de Acapulco. Seis años más tarde, se conformó la Comisión de Planificación Regional para vincular la evolución de Acapulco a la de su zona de influencia. En 1970 se aprueba el "Plan Acapulco" con el objetivo de elaborar y ejecutar programas de desarrollo integral, es decir, tanto relacionados con la dinámica urbana (infraestructura y servicios, renovación urbana, regularización de colonias populares, áreas verdes, etc.) como con la actividad turística (limpieza de las playas, control de la contaminación, planificación del desarrollo turístico, etc.). En 1976, a fin de disponer de una instancia de mayor margen de operación y con presupuesto propio, se aprobó el Fideicomiso Acapulco (FIDACA). ${ }^{54} \mathrm{Su}$ actividad planificatoria se materializó en la elaboración de un Plan Director Urbano que tuvo como apoyos operativos el Plan de Acciones Básicas y otros Planes Parciales; a partir de ambos, se puso en

54 El objetivo de FIDACA es: "coordinar los esfuerzos de autoridades federales, estatales y municipales en Acapulco para promover el desarrollo urbano, turístico, agropecuario, industrial y de servicios a corto, mediano y largo plazo". J. López Portillo: "Sexto Informe de Gobierno, Sector Asentamicntos Humanos", 1982, p. 145. Su decreto constitutivo define asi sus funciones: "adquirir, urbanizar, fraccionar, vender, arrendar, administrar bienes inmuebles y elaborar el plan de desarrollo urbano de la ciudad y coordinar su aplicación". 
marcha un "Plan Contingente 1981-1982". FIDACA enfocó sus acciones a obras de urbanización, mejoramiento urbano, suministro de agua potable y alcantarillado. Los proyectos que no lograron materializarse fueron la reubicación de la central de abastos y de la zona de tolerancia y los proyectos de nuevos desarrollos turísticos (Icacos y Puerto Marqués).

La lógica interna y la estrategia de fondo que guiaban el Plan de Acciones Básicas de FIDACA era estructurar dos zonas diferenciadas para el crecimiento de Acapulco: a) la costera este y oeste, así como el anfiteatro para el turismo y la construcción de complejos residenciales de lujo; $b$ ) la llanura del río de La Sabana (situado al norte y este del anfiteatro a ambos lados de la carretera MéxicoAcapulco) para la reubicación de colonias populares y de la nueva central camionera, central de abastos, reclusorio y zona de tolerancia, así como áreas de reserva para una futura ciudad industrial y las nuevas corrientes migratorias. El plan significaba claramente definir y separar dos Acapulcos: el primero ocuparía la bahía y estaría dedicado exclusivamente al turismo y el segundo sería la ciudad de los pobres y de las funciones urbanas necesarias pero que "desdicen" y es conveniente ocultar a los ojos de los visitantes, sobre todo extranjeros.

En los terrenos que se liberarían en el viejo centro de la ciudad (al ser reubicados diversas funciones y espacios) se construirian restaurantes, tiendas, almacenes, edificios y condominios. Y la zona del anfiteatro se convertiría en un parque nacional, aunque existían fundadas razones para pensar que terminaria siendo una zona residencial. No existe la menor duda de que se quería dar una imagen nueva de Acapulco y re-lanzarlo en el ámbito turístico internacional. Este ambicioso proyecto fue truncado por la crisis económica del país y por la oposición que provocó, entre los sectores populares en especial, la reubicación de colonos del anfiteatro. ${ }^{55}$

\section{Balance y perspectivas}

Acapulco es un centro turístico de indiscutible importancia a nivel internacional. La compleja y sofisticada infraestructura de que dispone permite que una parte de la actividad turística pueda realizarse fuera de las playas: deportes no acuáticos, espectáculos, restau-

55 Ramírez Sáiz J.M.: "El movimiento urbano popular en México", Siglo xxı Edit, 1986, pp. 94-103: El Consejo General de Colonias Populares de Acapulco; véase la serie de notas que sobre este tema publicó A. Mercado en el periódico Uno más Uno durante 1980 y 1981 . 
rantes, discotecas, centros nocturnos, etc. Su vida urbana y, sobre todo, nocturna (nacida bajo el señuelo de playas y aguas salinas) parecen ya casi no necesitar de ellas. Sin embargo, la acelerada e impresionante evolución de este balneario de playa pone de manifiesto varios hechos decisivos para la actividad turística y el medio ambiente:

a) la expropiación ventajosa de tierras ejidales y el uso del suelo, basado fundamentalmente en razones especulativas, anularon las propuestas planificatorias sobre la incorporación de tierra y el desarrollo de la ciudad;

b) el crecimiento desarticulado de la ciudad y la dotación insuficiente de infraestructuras, servicios y equipamiento urbanos, así como su desigual distribución entre los diferentes sectores de la ciudad y las instalaciones turísticas redundó en una estructura urbana disfuncional que ha sido negativa para el propio centro vacacional;

c) la tardía definición de criterios ambientales en el desarrollo de las actividades turísticas ha conllevado su estancamiento y pérdida de importancia tanto a nivel nacional como internacional;

d) el manejo irracional de los recursos naturales se ha traducido no sólo en el deterioro de la calidad de las aguas salinas sino también de la flora y fauna marinas, y

e) tanto la posición de las autoridades federales como de la entidad y del municipio hacia los empresarios del turismo en el puerto han sido de franco apoyo y de una excesiva tolerancia. ${ }^{56}$ El caso de la contaminación causada por los hoteles es sólo uno de los exponentes, aunque quizá el que peores consecuencias ha tenido para su propia fuente de ganancia.

En síntesis, la imprevisión (urbana y ambiental) así como el desarrollo (acelerado y sin medir los riesgos) del turismo están ahora siendo pagados no necesariamente por quienes los causaron y afectan la economía local, el medio ambiente y la calidad de la vida de sus habitantes y turistas.

La importancia del turismo para la economía nacional como una de las fuentes principales de obtención de divisas y en cuanto medio generador de empleo es indudable. $Y$, en este contexto, la aportación de Acapulco es altamente significativa. Por ello, es más notoria la evolución negativa que ha seguido este balneario de playa.

56 "Si las cadenas hoteleras internacionales se enriquecen con lo nuestro; si son gananciosas en grado mayor que el admisible es porque el gobierno ha sido omiso en establecer medidas legales adecuadas y en hacerlas cumplir y porque no se emprenden acciones que conduzcan a la corrección de estas situaciones anómalas". Uno más Uno, 18 de noviembre de 1981, editorial. 
Con posterioridad a la evidencia de los efectos que el tipo de desarrollo adoptado estaba teniendo para Acapulco, el gobierno ha desplegado una importante labor correctiva. Pero ésta ha sido rebasada por el lastre de un despegue y auge turístico no planificado, el limitado control ejercido sobre los agentes contaminantes, la explosión demográfica y la conducta ecocida de la población (residentes y turistas).

La raíz de los conflictos anteriores se encuentra en el modelo de desarrollo turístico en que se basó Acapulco. El turismo del puerto ha pasado por dos fases diferentes. La primera fue selectiva y excluyente y privilegió al turista elitista y extranjero siguiendo las pautas que introducen las cadenas hoteleras internacionales. La segunda corresponde a su etapa de masificación y, para responder a la cual, Acapulco no se hallaba suficientemente equipado. Pero, en ambos casos, se fundamentó en patrones impuestos por las firmas transnacionales, que funcionan a través de la estandarización de los servicios prestados e incluso de la conducta del turista, etc. Las reglas de funcionamiento se homogeneizan entre los diferentes países a fin de maximizar las utilidades. $Y$ cuando se aplican a países en desarrollo, no tienen en cuenta los requerimientos que el elemento a explotar - medio ambiente - plantea para el desarrollo al mayor largo plazo posible de la propia actividad turística. Es, en muchos casos, un modelo de eficiencia aparencial que, en el fondo, constituye un despojo sobre los recursos naturales.

Lo anterior no indica que el futuro turístico y ambiental de Acapulco vaya a ser necesariamente desastroso, pero sí problemático. El puerto de Acapulco, a pesar de mantenerse como el centro turístico más importante del país, está perdiendo presencia tanto a nivel nacional como internacional. Para recuperarla, es preciso aplicar nuevas medidas correctivas que para el puerto operarían también como preventivas de un deterioro ambiental mayor. La bahía puede descontaminarse mediante corrientes inducidas (inyectando aire con compresoras o ventiladores) que renueven periódicamente las aguas. Es preciso reforestar el anfiteatro para evitar el avance de la erosión. Debe aplicarse un control estricto sobre las descargas clandestinas de aguas residuales, la deposición de aceites y desperdicios en el agua, que realizan las embarcaciones, así como de basuras por parte de la población residente y flotante. Estas medidas han de ser complementadas con una ampliación del sistema de drenaje y su constante supervisión y mantenimiento. Asimismo urge encontrar soluciones fiscales aplicables a los hoteles, a través de las cuales se incrementen los recursos del municipio para financiar estas acciones. 
El balance de la experiencia de Acapulco refuerza dos principios básicos en la actividad turística: la planeación preventiva y el manejo adecuado de los recursos naturales.

La historia de Acapulco señala la necesidad imperiosa de una planeación indicativa o preventiva (tanto urbana como ambiental) de los centros turísticos. Al respecto, los aspectos menos atendidos siguen siendo los relacionados con el conocimiento preciso de los ecosistemas en cuestión, la identificación de los posibles elementos contaminantes, la localización de sus fuentes, la detección de sus conductores y destinos, así como sus posibles efectos; igualmente es conveniente avanzar en la determinación de estrategias para atenuar dichos efectos. Los responsables de este sector de la economía nacional intentan que los nuevos proyectos surjan como "centros turísticos integralmente planeados". Quizá su aspecto problemático sea que los cálculos y previsiones son realizados casi exclusivamente en función de los requerimientos urbanos y ambientales de la actividad turística y no tanto del asentamiento humano que implica todo proyecto y que, más pronto que tarde, genera. Por otra parte, no tiene en cuenta y sistemáticamente se encuentra desprotegido frente a las corrientes migratorias que propicia el surgimiento de estos polos de desarrollo turístico. Ello indica que la planeación turística y ecológica no puede desentenderse de la necesidad de tierra (en el corto y mediano plazo, es decir, disponibilidad presente y reservas territoriales), de la previsión de la demanda habitacional que manifestará la población residente y migrante, de la dotación de infraestructura y servicios urbanos (en particular, drenaje, recolección de basura, sistema de abasto, vialidad y transporte). Si ello rebasa el campo tradicional de la planeación turística y ecológica, tampoco ella puede desvincularse de estas exigencias "adicionales" salvo bajo el riesgo de un efecto boomerang que, en el corto o mediano plazo, revertirá sobre el centro turístico. Las características de cada proyecto condicionarán las soluciones posibles que pueden ir desde el establecimiento de alguna articulación entre estos requerimientos sociales y el proyecto urbano y ecológico de nuevos centros turísticos hasta la creación de una ciudad paralela a la del centro vacacional. Sin embargo, toda propuesta que excluya a la población residente, aun a la no directamente involucrada en el proyecto, adolecerá de una carga de marginación y términará siendo afectada por el crecimiento de esa población "no incluida".

A partir de la planeación preventiva, es preciso establecer un manejo adecuado de los recursos naturales que implique integrarlos al proyecto turístico para su mejor uso no sólo en términos inmediatos, sino sobre todo garantizando su conservación en el largo 
plazo. Ello significa la utilización del medio como un recurso limitado que debe ser objeto de una explotación racional, evitando su destrucción y cuidando su preservación y pervivencia en el tiempo. Los dos principios anteriores evidencian que la planeación (económica, urbana y ambiental) y la explotación correcta de los turísticos se convierten en una tarea trascendental.

\section{Bibliografía}

Aguirre, J., J. L. Calderón y F. Bahamonde, "Diagnóstico y solución a la problemática de la contaminación del agua del estado de Guerrero", PRI-IEPES-CEPES, noviembre, 1981 .

Calderón B., J. L. "Índice de calidad del agua", ponencia presentada en el XVII Congreso Interamericano de Ingenieria Sanitaria y Ambiental, julio, 180.

Cazes, G., "Les amenagements touristiques au Mexique", Centre de Hautes Etudes Touristiques, Aix-en-Provence, France, 1980, Etudes et Memoires núm. 38.

Cervantes D., A., "Cuatro In forme de Gobierno", Chilpancingo, 1985.

Cerruti, J., "The Twó Acapulcos", en National Geographic Magazine, 1964, núm. 12 , pp. $850-878$.

Conde G., N. R., "Algunas consideraciones sobre el desarrollo capitalista, la lucha de clases, la producción de estructura urbana y los procesos de ubanización en la región acapulqueña", tesis profesional, Facultad de Ciencias Politicas y Sociales, UNAM, 1982.

Crittendon, A., "Paraíso perdido por contaminación turística", en Revista Servicio, mayojunio, 1976.

Dioni, W., "Calidad bacteriológica de las playas de Acapulco, 1976-1982", ponencia presentada en el IV Congreso Nacional de Ingeniería Sanitaria y Ambiental, Memoria, vol. I, 1984, pp. 306-309.

Erbes, R., "Le tourisme international et l'economie des pays en voie de developpement", oCDE, Paris, 1973.

Fideicomiso Acapulco (FIDACA): "Plan de Acciones Básicas 1980-1982", México, Imprenta Venecia, 2 tomos, 1981. "Plan Director Urbano de Acapulco."

FonıtuR: "Estudio sobre la actividad turística en Acapulco, Guerrero", Gerencia de Planeación y Estudios Socioeconómicos, 1976.

Garibay, R., "Acapulco", Editorial Grijalbo, 1979.

Gomezjara, F., "Acapulco: despojo y turismo", en Revista Problemas del Desarrollo, UNAM, Instituto de Investigaciones Económicas, núm. 19, agosto-octubre, 1976 , pp. 126-145.

. "Acapulco: el paraiso perdido", en Revista Habitación, Fovissste, núm. 7-8, julio-diciembre, 1982, pp. 103-111.

Gómez Maganda, A., "Acapulco en mi vida y en mi tiempo", México, Costa Amic, 1955.

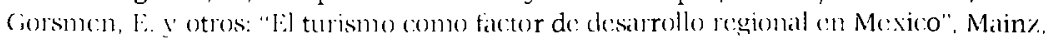
Alemania, 1977, mimeo.

Gutelman, M., "Capitalismo y reforma agraria en México", edic. Era, Méxice, 1974. Haulot, A., "Un certain tourisme", Secretariado General de la Organización Mundial del Turismo, Hainaut a Mons, Bélgica, 1983.

Instituto Mexicano de Investigaciones Turisticas, "Acapulco, Indicadores Económicos", s.f., mimeo

Jud, G.D., "Tourism and economic growth in Mexico since 1950", en Inter-American 
Economic Affairs, 28, 1, Washington, D. C., pp. 19-43.

López Portillo, J., "Sexto Informe de Gobierno", Sector Asentamientos Hum anos, 1982. Molina, S., "Turismo y ecología", edit. Trillas, México, 1983.

Moreno T., O., "La estructura internacional del negocio turístico", en Revista Comercio Exterior, núm. 7, julio, 1971.

" "La planeación del desarrollo turístico y el interés nacional", en Revista Servicio, noviembre-diciembre, 1974, pp. 8-11.

Movimiento Ecologista Mexicano, "Acapulco, grave riesgo", 1985, mimeo.

ONU, "Monografía mimeografiada sobre el desarrollo turístico de México desde 1950", 1971. Conferencia de las Naciones Unidas para el Comercio y Desarrollo (CNUCED).

De la Peña, M. T., "Guerrero Económico", México, Talleres Gráficos de Adrián Sánchez, 1949, tomo II.

Ramírez Sáiz, J. M., "Carácter y contradicciones de la Ley General de Asentamientos Humanos", edic. IIS-UNAM, 1983.

, "El movimiento urbano popular en México", Siglo XXI Editores, 1986

, "Política urbana y lucha popular", edic. UAM-X, (en prensa).

Rodríguez O., M. L., "El turismo como aparato cultural", UNAM-X, Cuadernos del TICOM, núm. 9, 1981 .

Rodríguez, S., y L. Qezada: "Solución al problema de contaminación por descargas de aguas residuales a la bahía de Acapulco", ponencia presentada en el II Congreso Nacional de Ingeniería Sanitaria y Ambiental, septiembre, 1982.

SAHOP, "Ecoplan del municipio de Acapulco", 1981.

, "Plan Municipal de Desarrollo Urbano de Acapulco".

- "Ecoplan Sectorial del Centro de Población de Acapulco".

SARH, Dirección General de Usos del Agua y Prevención de la Contaminación: "Bahía de Acapulco", 1980.

Secretarías de la Defensa Nacional de Marina y de Turismo, "Plan Contingente Acapulco, 1981-1982".

Secretaría de Marina, "Estudios de la población planctónica y sus relaciones con algunos parámetros físico-químicos en la bahía de Acapulco, Guerrero", Dirección General de Oceanografía, México, D.F., 1981

, "Configuración cotidal en la bahía de Acapulco, Guerrero, Dirección General de Oceanografía, México, D.F., 1979.

, "Estudio sobre la contaminación del agua en la bahía de Acapulco y proximidades". Tomo I. "Perfiles de distribución de temperatura y oxígeno disuelto", Dirección General de Oceanografia, México, D.F., 1979. Tomo II. Geomorfologia y procesos sedimentarios en la región costera de la bahía de Acapulco Guerrero, 1980.

, "Métodos preventivos para el control de la contaminación de las aguas de la bahía de Acapulco, Guerrero", Dirección General de Oceanografia, MéxiCo, D.F., 1980.

, "Cuantificación de substancias organocloradas en especies de importancia comercial y sedimentos, bahía de Acapulco, Guerrero", Dirección General de Oceanografía, México, D.F., 1980.

Secretaría de Patrimonio Nacional, Dirección General de Urbanismo: "Plan Acapul$\mathrm{co}^{\prime \prime}, 1971$.

, "Plan Director de Desarrollo Metropolitano Acapulco, Subsecretaría de Bienes Inmuebles y Urbanisticos, 1972, mimeo.

SECTUR, "Estadísticas Básicas de la Actividad Turística", México, 1985.

"Plan Nacional de Turismo", México, 1979

"Estudio sobre la actividad turística en Acapulco" agosto, 1983.

"La contaminación de las aguas de la bahía de Acapulco y su impacto 
en el desarrollo turístico", s.f., mimeo.

, "Programa Nacional de Turismo, 1984-1988".

, "Lineamientos para el desarrollo de normas de protección al entorno ecológico en sitios turísticos", México, 1979.

SEDUE, Dirección General de Prevención de la Contaminación del Agua, "Informe sobre Acapulco", mimeo, 1985.

, "Programa Nacional de Ecología, 1984-1988".

De la Torre, O., "El turismo, fenómeno social", Fondo de Cultura Económica, MéxiCo, 1984

Valencia, E. , "Turismo, urbanización y marginalidad", en Revista Habitación, Fovisssir., núm. 7-8, julio-diciembre, 1982, pp. 79-87. 